\title{
EFFECTS OF DEPOSITION TIME AND PH ON THE CHARACTERIZATION OF CHEMICALLY SYNTHESIZED COMPOSITE NANO-WIRES OF $\mathrm{CU}_{2} S$ THIN FILMS
}

\author{
Honar S. Ahmed ${ }^{\mathrm{a}, *}$, Raghad Y. Mohammed ${ }^{\mathrm{a}}$, Mohammed Hussein Khalil ${ }^{\text {a }}$ \\ ${ }^{\text {a }}$ Dept. of Physics, College of Science, University of Duhok, Duhok, Kurdistan Region, Iraq-(honar.salah, ssraghad and \\ mohamadswary)@uod.ac
}

Received: Nov., 2021 / Accepted: Dec., 2021 / Published: Dec., 2021

https://doi.org/10.25271/sjuoz.2021.9.4.863

\begin{abstract}
:
The chemical bath deposition technique (CBD) had used for depositing $\mathrm{Cu}_{2} \mathrm{~S}$ thin films on the glass substrates. It found that thickness and deposition rate were significantly dependent on deposition parameters (deposition time and $\mathrm{pH}$ value). XRD data indicates that at different deposition times and $\mathrm{pH}$ values are given amorphous structure except for the deposited thin film of (8hours) and, $\mathrm{pH}$ of (10.4) the structure was crystalline. The morphology of the deposited thin films remarkably changed as the deposition time increased. Optical transmittance measurements illustrate that transmission of the thin films decreases from $93.27 \%$ for a deposition time of 4 hours to 81.73 for deposition time of 10 hours and, the maximum transmission rate of the films is $95.21 \%$ with pH=8.4 and decreases to $28.39 \%$ with $\mathrm{pH}=11.4$. Also, optical studies revealed that $\mathrm{Cu}_{2} \mathrm{~S}$ thin film with direct energy bandgap decreased from 3.04 to 2.78 $\mathrm{eV}$ as deposition time increased and from 3.09 to $2.32 \mathrm{eV}$ as $\mathrm{pH}$ increased.
\end{abstract}

KEYWORDS: $\mathrm{Cu}_{2} \mathrm{~S}$ thin film, CBD, Bandgap, thin-film, optical properties, XRD

\section{INTRODUCTION}

Nowadays, there is a huge increment in the study of nanoscale semiconducting materials due to the properties in nano shapes varying essentially from those of their bulk counterparts (Shinde et al., 2012). Besides nontoxic and abundant materials in the earth's crust, such as the transition metal chalcogenides (sulfides, tellurides, and oxides), are critical of considering for the advancement of innovative materials. The investigation has extended due to their fabulous physical and chemical properties(CRUZ et al., 2012).

$\mathrm{Cu}_{2} \mathrm{~S}$ is a well-known material because of its significant optical and electrical properties which allow copper sulphide to be utilized in different important applications (Ismail et al., 2020) such as optoelectronic devices (Kim et al., 2017), absorbers for solar energy conversion (Ghdeeb, 2015), ion batteries and superconductors (Li et al., 2017; Liu et al., 2018), gas sensors (Sagade \& Sharma, 2008), heterojunction photodetectors such as $\mathrm{Cu} 2 \mathrm{~S} / \mathrm{CdS}, \mathrm{ZnO} / \mathrm{Cu} 2 \mathrm{~S}, \mathrm{Cu} 2 \mathrm{~S} / \mathrm{ZnS}$ and $\mathrm{Cu} 2 \mathrm{~S} / \mathrm{n}-\mathrm{Si}$ (Guo et al., 2014; Ismail et al., 2019; Zhan et al., 2020), and supercapacitors (Bulakhe et al., 2016).

The $\mathrm{Cu}_{\mathrm{x}} \mathrm{S}$ system has five stable phases: chalcocite $\left(\mathrm{Cu}_{2} \mathrm{~S}\right)$, djulerite $\left(\mathrm{Cu}_{1.97} \mathrm{~S}\right)$, digenite $\left(\mathrm{Cu}_{1.8} \mathrm{~S}\right)$, anilite $\left(\mathrm{Cu}_{1.75} \mathrm{~S}\right)\left(\mathrm{Cu}_{1.4} \mathrm{~S}\right)$ and yarrowite $\left(\mathrm{Cu}_{1.12} \mathrm{~S}\right)$ these are referred to as blaubleibender covellite (CRUZ et al., 2012). copper sulphide could have a variety of crystal structures according to the value of $X$, such as orthorhombic, pseudo cubic, hexagonal, and tetragonal (Pathan \& Lokhande, 2004). For instance, $\mathrm{Cu}_{2} \mathrm{~S}$ has a hexagonal structure, whereas $\mathrm{Cu}_{2} \mathrm{~S}$ could be found in both orthorhombic and hexagonal crystal structures (Buba \& Adelabu, 2009). $\mathrm{Cu}_{2} \mathrm{~S}$ is a binary p-type Semiconductor with a bulk band gap of $1.2 \mathrm{eV}$ (Ha et al., 2021). Many different techniques were used for the deposition of $\mathrm{Cu}_{2} \mathrm{~S}$ for example pulsed laser deposition (Maji et al., 2013), successive ionic layer absorption and reaction (SILAR)(Pathan et al., 2002), atomic layer deposition (Schneider et al., 2016), spray pyrolysis (Isac et al., 2007; Nho et al., 2012), chemical bath deposition (CBD) (Ishii et al., 1993; Ismail et al., 2020; Manjulavalli \& Kannan, 2015; Muhammed et al., 2019), and photochemical deposition (Podder et al., 2005). The most popular thin films deposition technique is the chemical bath deposition (CBD) because it has many advantages over the other deposition techniques such as large deposited thin film area, costeffective, low temperature and no high pressure or vacuum needed for the deposition process (OMWOYO, 2019). Besides, it has a limitation regarding the temperature of deposition. The temperature is normally restricted to about $\left(100{ }^{\circ} \mathrm{C}\right)$, the inefficiency of the process, in terms of the utilization of starting materials and their conversion to thin films, the generation and disposal of large quantities of hazardous waste (Hodes, 2002; Lee, 2007), inadequate mixing of the reactants, and lack of control over reaction processing time (Kırmızıgül et al., 2013). Many parameters have to be noticed during the deposition process by CBD technique such as deposition time, bath temperature, $\mathrm{pH}$ value, and chemical reagents because they have a great effect on the deposited thin films' properties.

In this work, the $\mathrm{CBD}$ technique was utilized to deposit $\mathrm{Cu}_{2} \mathrm{~S}$ nanowire thin films on a glass substrate. Its structural, morphological, and optical properties have been examined concerning deposition parameters (time of deposition and $\mathrm{pH}$ value).

\section{EXPERIMENT}

Glass slides of the dimensions $(25 \times 75 \times 1 \mathrm{~mm})$ were used as substrates. Initially, the substrates were steeped for 24 hours in Chromic Acid to create nucleation sites in the glass substrates then washed in distilled water before being rinsed in Ethanol to

* Corresponding author

This is an open access under a CC BY-NC-SA 4.0 license (https://creativecommons.org/licenses/by-nc-sa/4.0/) 
remove impurities on the glass substrate. Finally cleaned with distilled water and air-dried.

Analytical grade chemicals with purity (99.6\%) copper (II) chloride dihydrate $\left(\mathrm{CuCl}_{2} .2 \mathrm{H}_{2} \mathrm{O}\right)$ as a $\mathrm{Cu}^{+}$ions source, thiourea [SC $\left(\mathrm{NH}_{2}\right)_{2}$ ] which represent a source of $\mathrm{S}^{-}$ions with $15 \%$ aqueous ammonia $\left(\mathrm{NH}_{3}\right)$ as a complexing agent were used for deposit $\mathrm{Cu} 2 \mathrm{~S}$ thin film. All chemicals were acquired from pro analysis ACS company. First, $50 \mathrm{ml}$ of $0.2 \mathrm{M}\left(\mathrm{CuCl}_{2} \cdot 2 \mathrm{H}_{2} \mathrm{O}\right)$ was mixed with an appropriate amount of a complexing agent which was $(15 \%)$ Ammonia solution to obtain the purposed $\mathrm{pH}$ of the solution. After a few minutes and under continuous stirring the solution becomes dark blue and uniform which indicates the copper's ions formation. After that $50 \mathrm{ml}$ of $0.1 \mathrm{M}$ thiourea [SC $\left(\mathrm{NH}_{2}\right)_{2}$ ] was added to the solution. The precleaned substrates were submerged vertically in the solution at room temperature $\left(20^{\circ} \mathrm{C} \pm 2{ }^{\circ} \mathrm{C}\right)$. The deposition process was executed at various deposition times 4,6,8 and 10 hours while other parameters kept constant $\left(\mathrm{pH}=10.4, \mathrm{CuCl}_{2} .2 \mathrm{H}_{2} \mathrm{O}=0.2 \mathrm{M}, \mathrm{SC}\left(\mathrm{NH}_{2}\right)_{2}=0.1 \mathrm{M}\right)$ and different $\mathrm{pH} 8.4,9.4,10.4$ and 11.4 while other parameters kept constant $\left(\mathrm{Dt}=8\right.$ hours, $\mathrm{CuCl}_{2} .2 \mathrm{H}_{2} \mathrm{O}$ conc. $=0.2 \mathrm{M}, \mathrm{SC}\left(\mathrm{NH}_{2}\right)_{2}=$ $0.1 \mathrm{M})$. The different steps for the formation of $\mathrm{Cu} 2 \mathrm{~S}$ are shown in figure 1 .

An optical interferometer technique was used for measuring $\mathrm{Cu}_{2} \mathrm{~S}$ thin film thickness. Where equation (1) was used for calculating the thickness of the deposited thin films.
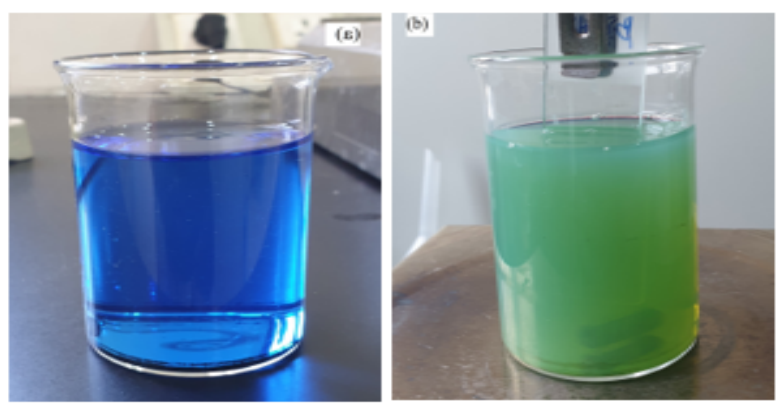

$$
d=\frac{\Delta x}{x} \frac{\lambda}{2}
$$

where

He-Ne laser wavelength $(\lambda=632.8 \mathrm{~nm}), \Delta x$ is the distance between two fringes, and $x$ is the width of the fringe (Chopra, 1969).

The X-Pert Pro PANalytical X-ray diffraction system was used to study the Structural properties of the $\mathrm{Cu}_{2} \mathrm{~S}$ thin films with $\mathrm{CuK} \alpha$ radiation $\left(1.5406 \mathrm{~A}^{\circ}\right)$ in the $2 \theta$ range $\left(10^{\circ}-80^{\circ}\right)$. The morphological properties of the surface of the $\mathrm{Cu}_{2} \mathrm{~S}$ thin films were studied by MIRA 3 TESCAN scanning electron microscopy (SEM). The optical transmission spectrums of the $\mathrm{Cu}_{2} \mathrm{~S}$ thin films were recorded by JENWAY $6850 \mathrm{UV} / \mathrm{Vis}$ spectrophotometer in the range of 350-1100 nm.

Tauc's equation was used to calculate the direct energy bandgap of the $\mathrm{Cu}_{2} \mathrm{~S}$ nanowires thin films (Makuła et al., 2018).

$$
(\alpha h v)^{2}=B(h v-E g)^{n}
$$

where the bandgap energy $(\mathrm{Eg})$, the transmittance $(\mathrm{T})$, the absorption (A), the absorption coefficient $(\alpha)$ that is given by ( $\alpha$ $=2.303 \log (\mathrm{T} / \mathrm{d})$ ), is the incident photon energy (hv), $\mathrm{n}$ depends on the transmission type (equals to $1 / 2$ for allowed direct transmission and 2 for indirect transition), and the film thickness (d) (Makuła et al., 2018; Mohammed et al., 2020).
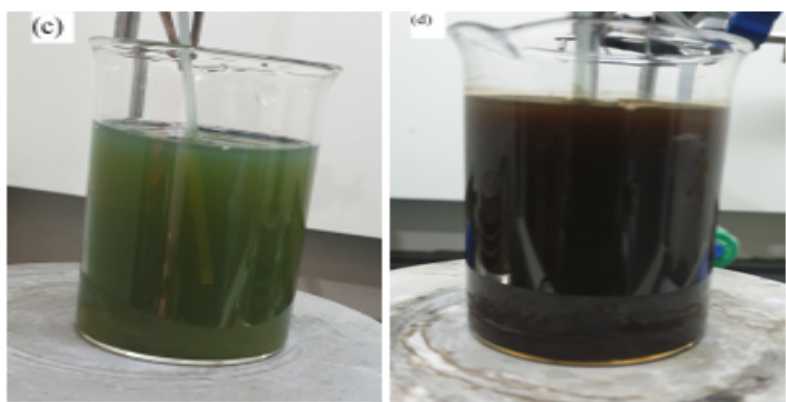

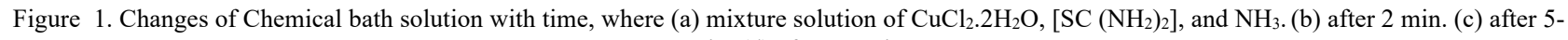
$7 \mathrm{~min}$. (d) after $20 \mathrm{~min}$.

\section{RESULTS AND DISCUSSION}

\subsection{Thickness and Growth rate}

Thin film deposition occurs successfully when the ionic product transcends the solubility product of $\mathrm{Cu}_{2} \mathrm{~S}\left(\mathrm{~K}_{\mathrm{sp}}=5 \times 10^{-48}\right)$ and the bath solution becomes supersaturated. The precipitation begins with subsequent combinations of ions on the glass substrate surface and the formation of nuclei in solution (Offiah et al., 2012).

Figure 2 shows the variation of $\mathrm{Cu}_{2} \mathrm{~S}$ nanowires thin films thickness with deposition time and $\mathrm{pH}$ value.

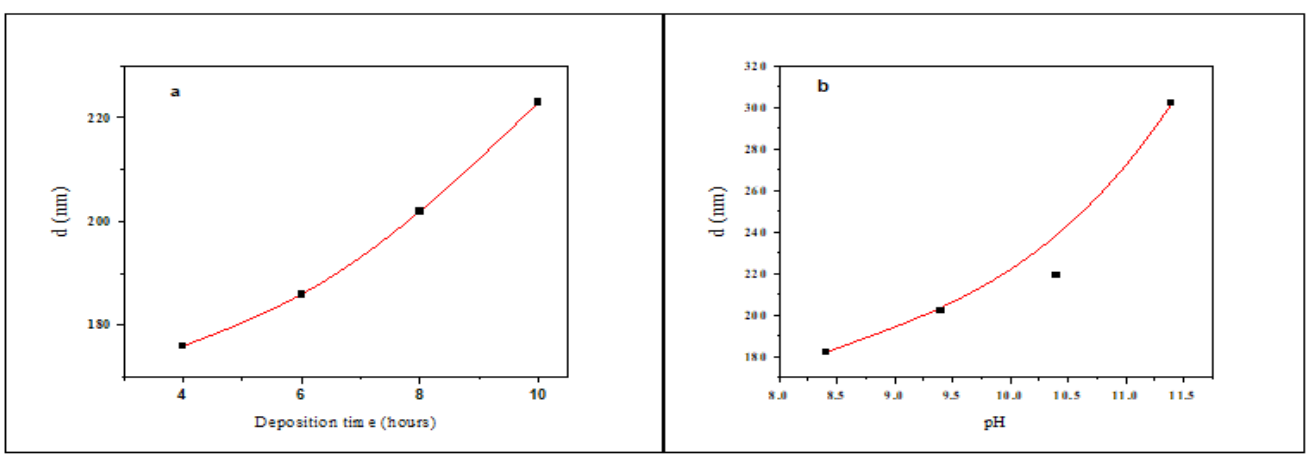

Figure 2. The variation of thickness of $\mathrm{Cu}_{2} \mathrm{~S}$ nanowires thin film with a) deposition time and, b) $\mathrm{pH}$. 
Figure 2a shows a smoothly increase of the thickness as the increasing of deposition time from 4 hrs. to $10 \mathrm{hrs}$. The growth curve (figure $2 \mathrm{a}$ ) reveals no thin film growth observed in the initial induction phase. The induction period then commences, followed by a systematic growth phase that begins with increasing film thickness as deposition time increases. This can also be deduced from the changing in the films' colour from grey colour for thickness(176nm) to dark grey for thickness(223nm). The thickness of the $\mathrm{Cu}_{2} \mathrm{~S}$ nanowires films with $\mathrm{pH}$ can be seen in figure $2 \mathrm{~b}$. It can be seen that the thickness increased from (182 to 302$) \mathrm{nm}$ when the $\mathrm{pH}$ value increased from (8.4 to 11.4). As observed in figure $2 \mathrm{~b}$, an increase in $\mathrm{pH}$ value leads to an increased growth rate. The reaction of thiourea hydrolysis will be pushed ahead this attributes due to the increase of $\mathrm{OH}^{-}$ions concentration in the solution, increasing sulfide ion source generation, as shown in Eq. 4-5 (Vas-Umnuay \& Chang, 2013): $\left(\mathrm{NH}_{2}\right)_{2} \mathrm{CS}+\mathrm{OH}^{-} \leftrightarrow \mathrm{CH}_{2} \mathrm{~N}_{2}+\mathrm{H}_{2} \mathrm{O}+\mathrm{HS}^{-}$

$\mathrm{HS}^{-} \leftrightarrow \mathrm{S}^{2-}+\mathrm{H}^{+}$

There is no indication of saturation in both cases (Fig.2a and $2 \mathrm{~b}$ ). The variation of growth rate as a function of deposition time and $\mathrm{pH}$ value is shown in figure 3 .

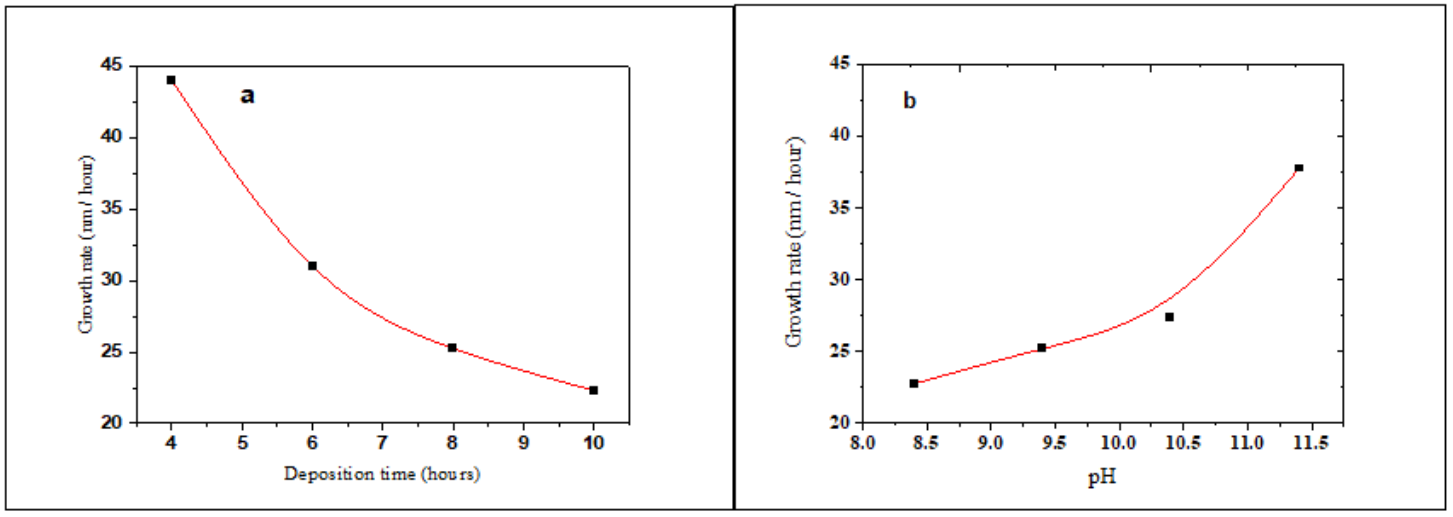

Figure 3. The variation of the growth rate of $\mathrm{Cu}_{2} \mathrm{~S}$ nanowires thin films with a) deposition times and, b) $\mathrm{pH}$.

The growth rate decreased from (44 to $22.3 \mathrm{~nm} /$ hour) as the deposition time increased from (4 to 10 hours) as shown in figure $3 a$. This can be attributed to the precursor consumption over time (Mohammed et al., 2020). While in figure 3b. the growth rate increase from $22.75 \mathrm{~nm} /$ hour to $37.75 \mathrm{~nm} /$ hour as the $\mathrm{pH}$ increased from 8.4 to 11.4. This is because the concentration of
$\mathrm{OH}^{-}$ions increase in the solution, which accelerates the thiourea hydrolysis reaction. (Vas-Umnuay \& Chang, 2013).

\subsection{Structure properties of $\mathrm{Cu}_{2} \mathrm{~S}$ thin films}

Figure 4. shows the XRD pattern of $\mathrm{Cu} 2 \mathrm{~S}$ thin films deposited at varied deposition times $(4,6,8$, and 10 hours).

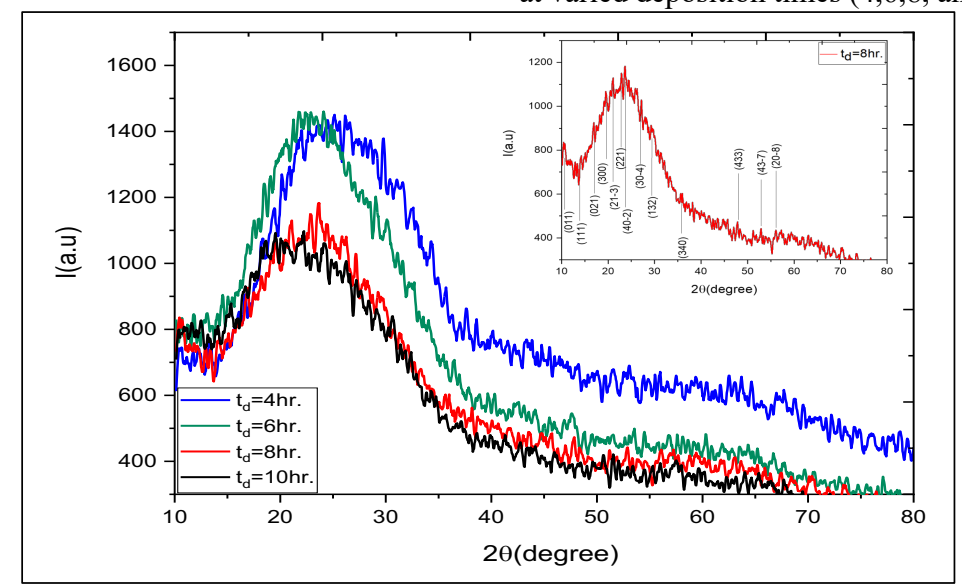

Figure 4. $\mathrm{XRD}$ pattern of $\mathrm{Cu}_{2} \mathrm{~S}$ nanowires thin films deposited at various deposition times at room temperature, $\mathrm{pH}=10.4, \mathrm{CuCl}_{2} .2 \mathrm{H}_{2} \mathrm{O}=0.2 \mathrm{M}$ and, $\mathrm{SC}\left(\mathrm{NH}_{2}\right)_{2}=0.1 \mathrm{M}$.

Figure 4. reveals that all deposited thin films give an amorphous structure except at a deposition time of 8 hours which is the optimum deposition time of $\mathrm{Cu}_{2} \mathrm{~S}$ nanowires thin film. It can be seen that the obtained XRD peaks of the diffraction patterns have been indexed as $\mathrm{Cu}_{2} \mathrm{~S}$ monoclinic-beta phase of copper sulfide according to the standard database spectrum (CPDS Card Code No. 829). In addition to that, no other peaks were detected from the other phases of copper sulfide, copper oxides, defects and impurities, which prove the high purity of the $\mathrm{Cu}_{2} \mathrm{~S}$ nanocrystal monoclinic-beta phase. Furthermore, it can be seen that their crystalline structure exhibits peaks corresponding to (011),
(111), (021), (300), (21-3), (221), (40-2), (3 $\left.0 \begin{array}{ll}3 & 0\end{array}\right),\left(\begin{array}{lll}1 & 3 & 2\end{array}\right)$ ,(340),(433),(43-7), and(20-8) planes. Figure 5. shows the $\mathrm{Cu}_{2} \mathrm{~S}$ thin films XRD pattern deposited at different $\mathrm{pH}$ values $(8.4,9.4$, 10.4 and 11.4).

All deposited $\mathrm{Cu}_{2} \mathrm{~S}$ films give an amorphous structure in which no diffraction peaks are found in both spectra. However, increasing the $\mathrm{pH}$ of the bath solution leads to an increase in the crystallinity of the deposited films. But, increasing the $\mathrm{pH}$ to 11.4

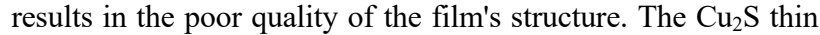
films deposited at $\mathrm{pH}=10.4$ had the corresponding optimum 
crystallinity structure exhibits to the crystalline peaks that reported above. These patterns are in good agreement with earlier reported studies (Allouche et al., 2010). The broad hump in figures (4 and 5) is due to the glass substrate.

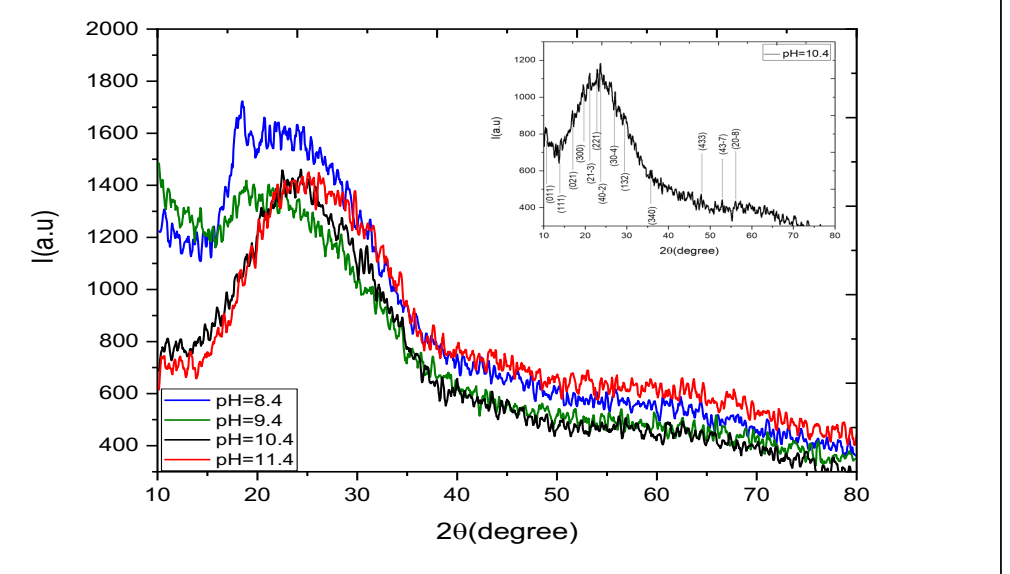

Figure 5. XRD pattern of deposited $\mathrm{Cu}_{2} \mathrm{~S}$ thin films at various $\mathrm{pH}$ values, constant bath temperature (room temperature), deposition time ( 8 hours), precursor concentration of $\left(\mathrm{CuCl}_{2} \cdot 2 \mathrm{H}_{2} \mathrm{O}=0.2 \mathrm{M}\right)$ and $\mathrm{SC}\left(\mathrm{NH}_{2}\right)_{2}=0.1 \mathrm{M}$.

\subsection{Morphological properties:}

One of the most promising techniques for studying sample topography is a scanning electron microscope. Figure 6, shows the FESEM images of $\mathrm{Cu}_{2} \mathrm{~S}$ thin film deposited at different deposition times.

It can be seen from figure (6) that thin films are relatively well synthesized, homogeneous and uniformly covered with some cracks, compact and agglomerations inceased as deposition time increased. Besides, this indicates that more nucleation sites have been formed and the number of grains has increased. Also, one can notice that the deposited thin films morphology remarkably changed with the increase of the deposition time. Thin films deposited at (4, 6, and 10 hours) surface were covered with nanowires with average size $(27.43,35.18$ and $27.6 \mathrm{~nm})$ and a few nanoparticles with average size $(30.14,25.49$ and 20.14), respectively. While thin film deposited at deposition time $(8$ hours) covered with nanoparticles with average size $(30.36 \mathrm{~nm})$.
Figure 7. shows the FESEM images of deposited films at various $\mathrm{pH}$ values. It is obvious from figure 6 that the $\mathrm{Cu}_{2} \mathrm{~S}$ thin films surface deposited at $\mathrm{pH}$ values $(8.4,9.4$ and 11.4) covered with nanoparticles with average size $(28.68,30.69$ and $33.61 \mathrm{~nm})$. While, the $\mathrm{Cu} 2 \mathrm{~S}$ thin film surface deposited at $\mathrm{pH}$ value (10.4) is covered with nanowires and nanoparticles with average size $(27.12$ and 29,14), respectively. FESEM images confirmed that the agglomerations and the number of clusters increased as $\mathrm{pH}$ increased. An increasing of $\mathrm{pH}$ leads to the increase of $\mathrm{OH}^{-}$ions which can cause noticeable morphological, shape changes and modify the repulsion and attraction forces. The increase of $\mathrm{OH}^{-}$ ions concentration pushes the reaction forward, weaken the repulsive forces, increase the attractive forces and allow the growth of oriented attachment (OA). when particles arrange perfectly with each other, the common boundary is eliminated, resulting to form the larger well-defined morphology particles (Xu et al., 2014; Yu et al., 2014), so the OA growth strongly depends on the $\mathrm{pH}$ (Reyes et al., 2018) as shown in figure 7.
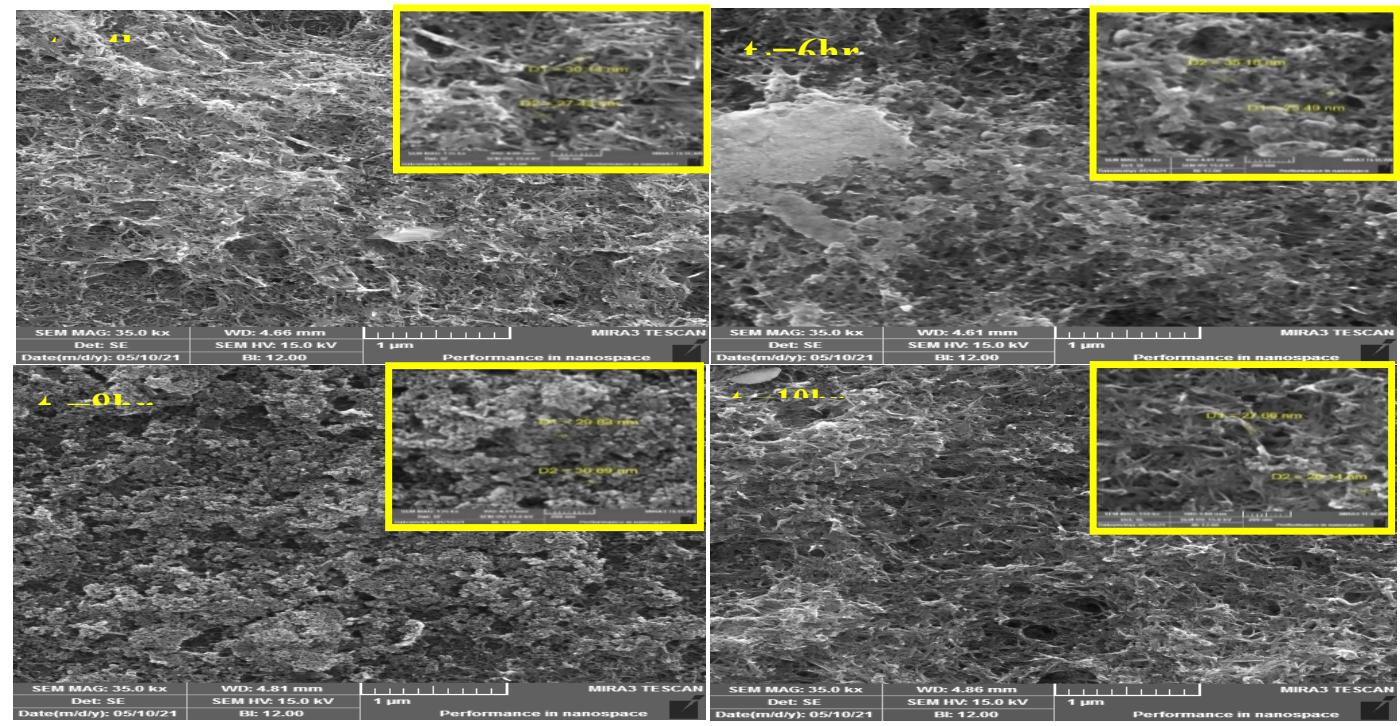

Figure 6. $\mathrm{SEM}$ images of $\mathrm{Cu}_{2} \mathrm{~S}$ films deposited at various deposition times at room temperature, $\mathrm{pH}=10.4, \mathrm{CuCl}_{2} .2 \mathrm{H}_{2} \mathrm{O}=0.2 \mathrm{M}$, and $\mathrm{SC}\left(\mathrm{NH}_{2}\right)_{2}=$ $0.1 \mathrm{M}$. 

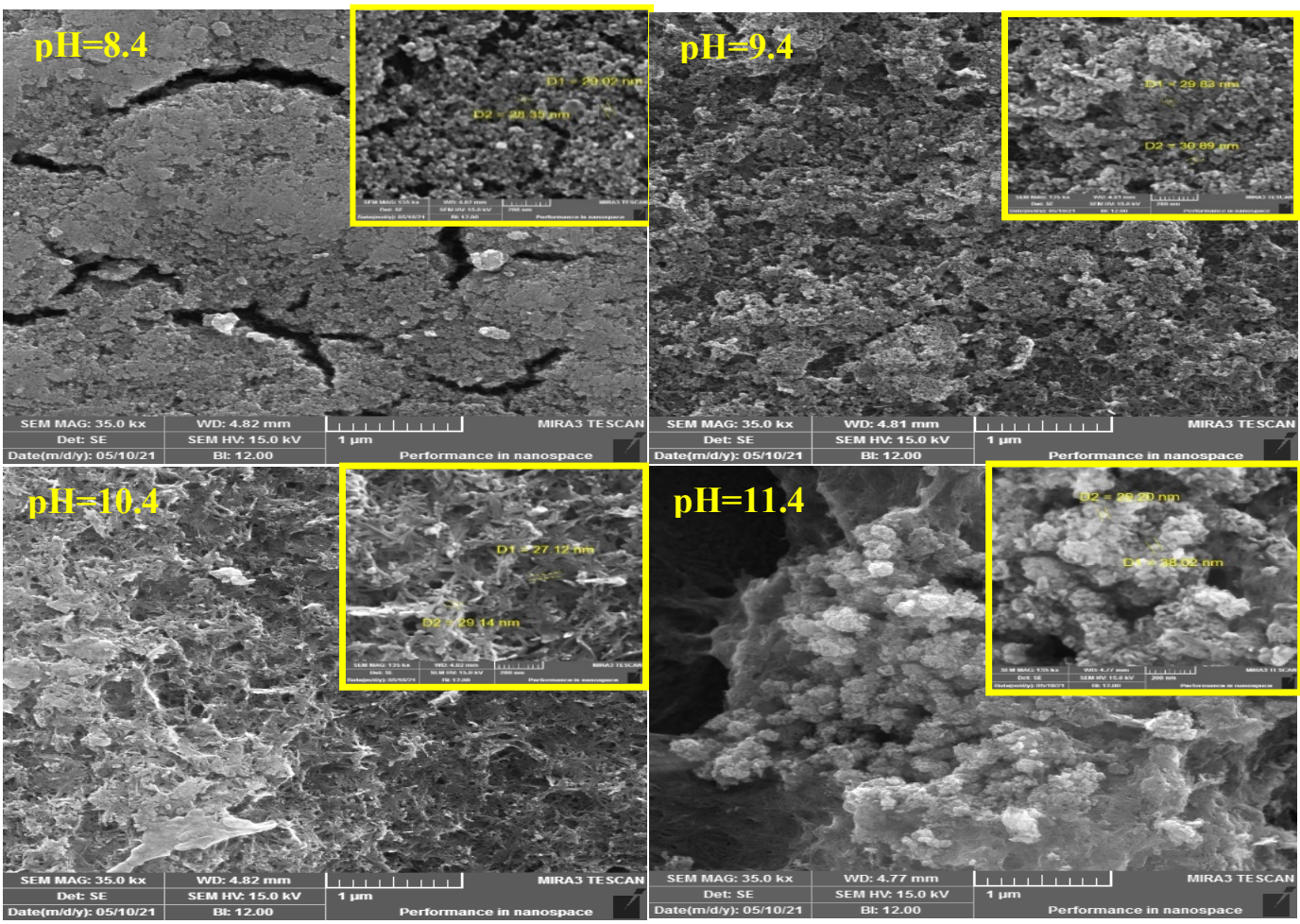

Figure 7. SEM images of $\mathrm{Cu}_{2} \mathrm{~S}$ films deposited at various $\mathrm{pH}$ values at room temperature, $\mathrm{t}_{\mathrm{d}}=8$ hours, $\mathrm{CuCl}_{2} \cdot 2 \mathrm{H}_{2} \mathrm{O}=0.2 \mathrm{M}$, and $\mathrm{SC}\left(\mathrm{NH}_{2}\right)_{2}=0.1 \mathrm{M}$.

\subsection{Optical properties}

3.4.1 Effect of deposition time: optical transmittance and absorbance spectra of $\mathrm{Cu}_{2} \mathrm{~S}$ thin films deposited at various deposition times can be seen in Figure 8.

From figure $(8 \mathrm{a})$. according to the absorbance measurements of the films weak absorption is observed at longer wavelengths whereas high absorption is acquired at shorter wavelengths (UVVIS). The absorption of the thin films increased as wavelength decreased to visible and NIR region. This makes the films to be suitable for use as thin coatings on windows to control the amount of light that enters a building and also reflect as much infrared radiation as possible. While, from figure $(8 b)$, one can see that the transmission of the thin films decreases from $93.27 \%$ for a deposition time of 4 hours to $81.73 \%$ for deposition time of 10 hours and this is attributed due to the increase in the films' thickness (Ghdeeb, 2015). Increasing the thickness of $\left(\mathrm{Cu}_{2} \mathrm{~S}\right)$ thin films leads to an increase in the depth of donor levels associated with these vacancies increases which cause these levels to be available for photons to be absorbed. As a result, the absorbance of $\mathrm{Cu}_{2} \mathrm{~S}$ thin films increases as well. figure (9) shows the absorption coefficient of $\mathrm{Cu}_{2} \mathrm{~S}$ thin films versus wavelength for different deposition times.
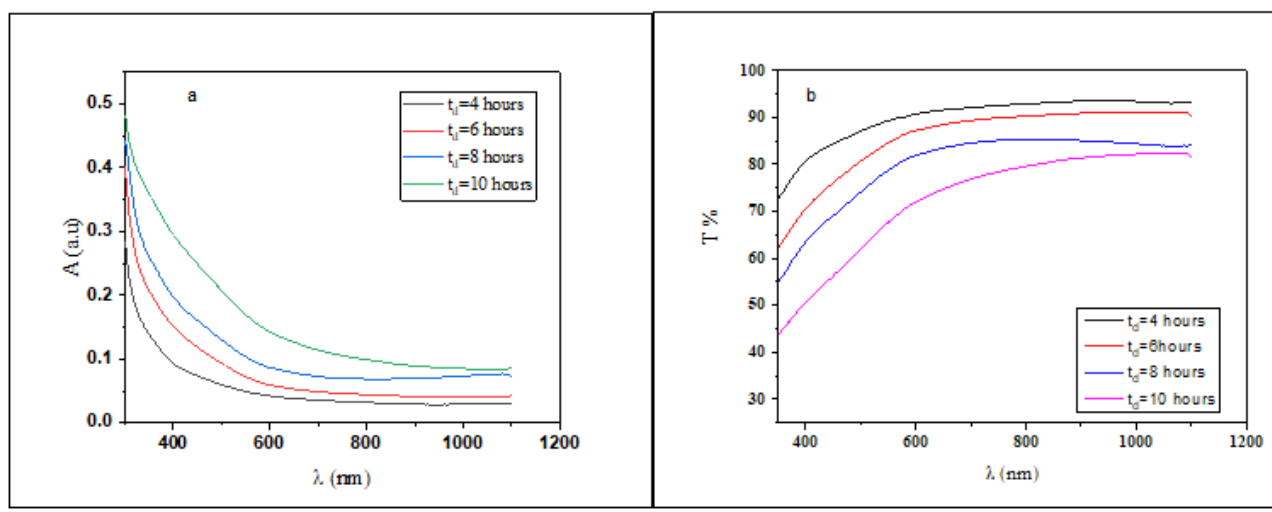

figure -8 a: Absorption spectrums of $\mathrm{Cu}_{2} \mathrm{~S}$ thin films at various deposition times versus wavelength b: transmission spectrums of $\mathrm{Cu}_{2} \mathrm{~S}$ thin films at various deposition times versus wavelength with $\mathrm{pH}=10.4, \mathrm{CuCl}_{2} .2 \mathrm{H}_{2} \mathrm{O}=0.2 \mathrm{M}$, and $\mathrm{SC}\left(\mathrm{NH}_{2}\right)_{2}=0.1 \mathrm{M}$. 


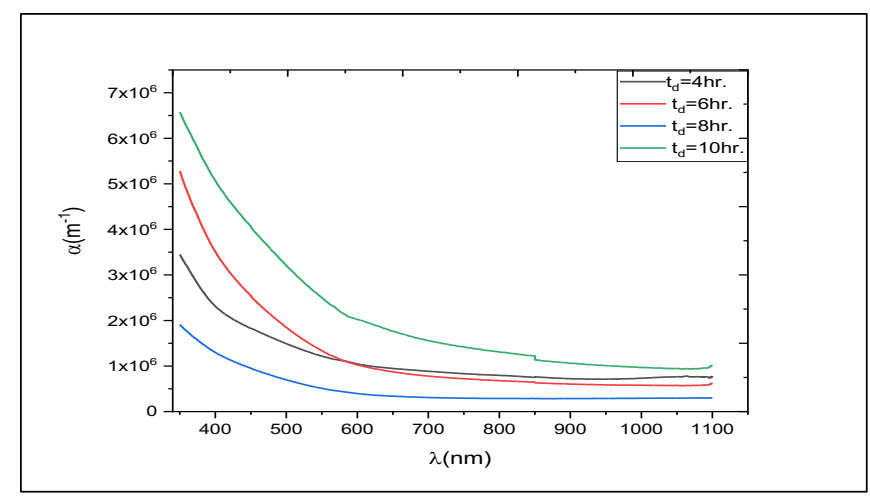

Figure -9 Absorption coefficient of $\mathrm{Cu}_{2} \mathrm{~S}$ thin films versus wavelength with $\mathrm{pH}=10.4, \mathrm{CuCl}_{2} .2 \mathrm{H}_{2} \mathrm{O}=0.2 \mathrm{M}$, and $\mathrm{SC}\left(\mathrm{NH}_{2}\right)_{2}=0.1 \mathrm{M}$.

The high absorption coefficient of $\mathrm{Cu}_{2} \mathrm{~S}$ thin films $\left(\sim 2 \times 10^{6}-6.5\right.$ $\times 10^{6} \mathrm{~m}^{-1}$ ) for deposition time of 4 hours to 10 hours, indicates the direct transition band gap of the films (Ismail et al., 2019). The direct energy band gap of $\mathrm{Cu}_{2} \mathrm{~S}$ thin films was calculated from the plot of $(\alpha h v)^{2}$ versus (hv) as shown in figure 10. Increasing the deposition time from 4 to 10 hours cause a reduction in the energy bandgap from 3.04 to $2.78 \mathrm{eV}$ and this is shown in figure
11. These decrease in the energy gap of the $\mathrm{Cu}_{2} \mathrm{~S}$ thin films may be attributed due to the transition from a poor crystalline to a polycrystalline state (Kırmızigül et al., 2013) or the film composition (Isac et al., 2013). The obtained energy gap values are approximately the same values obtained by (Ismail et al., 2020).

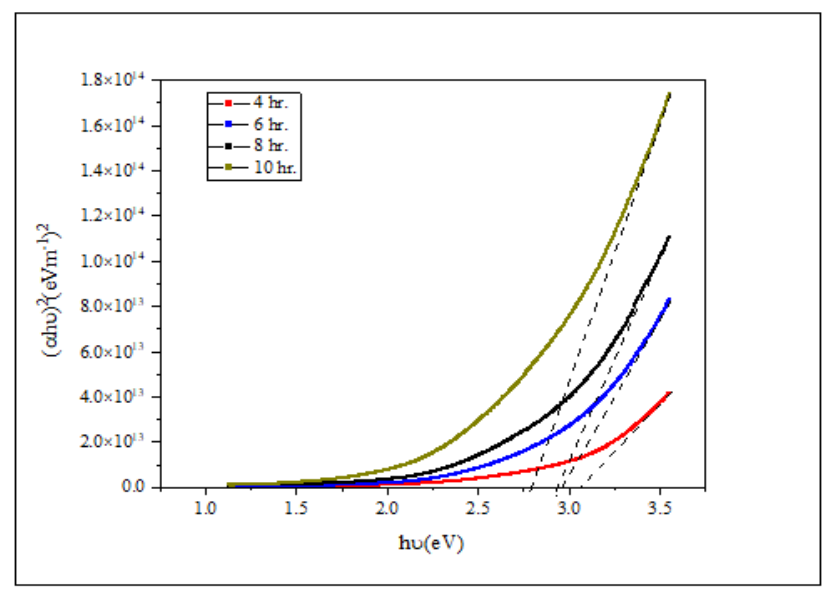

Figure 10. $(\alpha \mathrm{hv})^{2}$ with (hv) at various deposition times (4,6,8 and 10 hours) at $\mathrm{pH}=10.4, \mathrm{CuCl}_{2} .2 \mathrm{H}_{2} \mathrm{O}=0.2 \mathrm{M}$, and $\mathrm{SC}\left(\mathrm{NH}_{2}\right)_{2}=0.1 \mathrm{M}$.

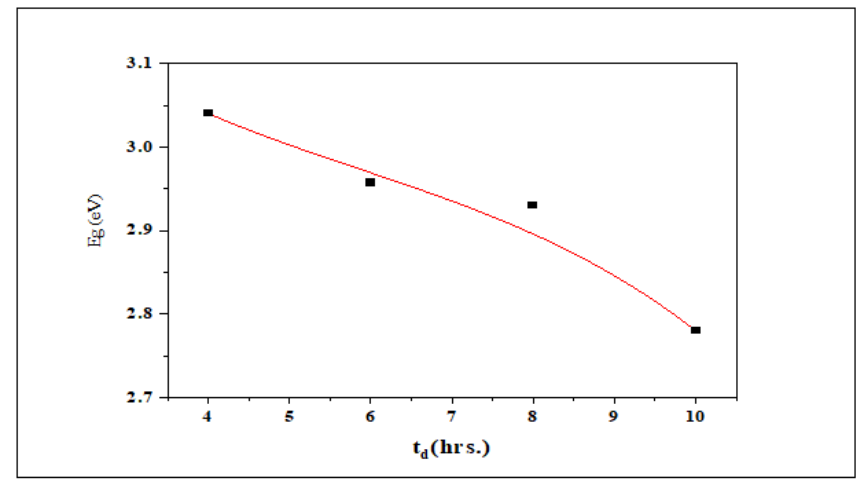

Figure 11. the variation of energy band gap of $\mathrm{Cu}_{2} \mathrm{~S}$ thin film with deposition times $(4,6,8$ and 10 hours $)$ at $\mathrm{pH}=10.4, \mathrm{CuCl}_{2} .2 \mathrm{H}_{2} \mathrm{O}=0.2 \mathrm{M}$, and $\mathrm{SC}\left(\mathrm{NH}_{2}\right)_{2}=0.1 \mathrm{M}$.

3.4.2 Effect of pH: the effect of the various $\mathrm{pH}$ values of the bath solution on the $\mathrm{Cu}_{2} \mathrm{~S}$ thin films' transmission and absorbance spectracan be seen figure 12 .
Optical transmittance measurements illustrate that the maximum transmission rate of the films is $95.21 \%$ with $\mathrm{pH}=8.4$ and decreases to $28.39 \%$ with $\mathrm{pH}=11.4$ in the visible range. The decrease of transmission is due to the increase in films thickness 
(Ghdeeb, 2015). While the absorption is $8.47 \%$ for $\mathrm{pH}=11.4$ and decreased to $1.6 \%$ for $\mathrm{pH}=8.4$ in the visible range.
Figure (13) shows the absorption coefficient of $\mathrm{Cu}_{2} \mathrm{~S}$ thin films versus wavelength for different $\mathrm{pH}$ growth condition.

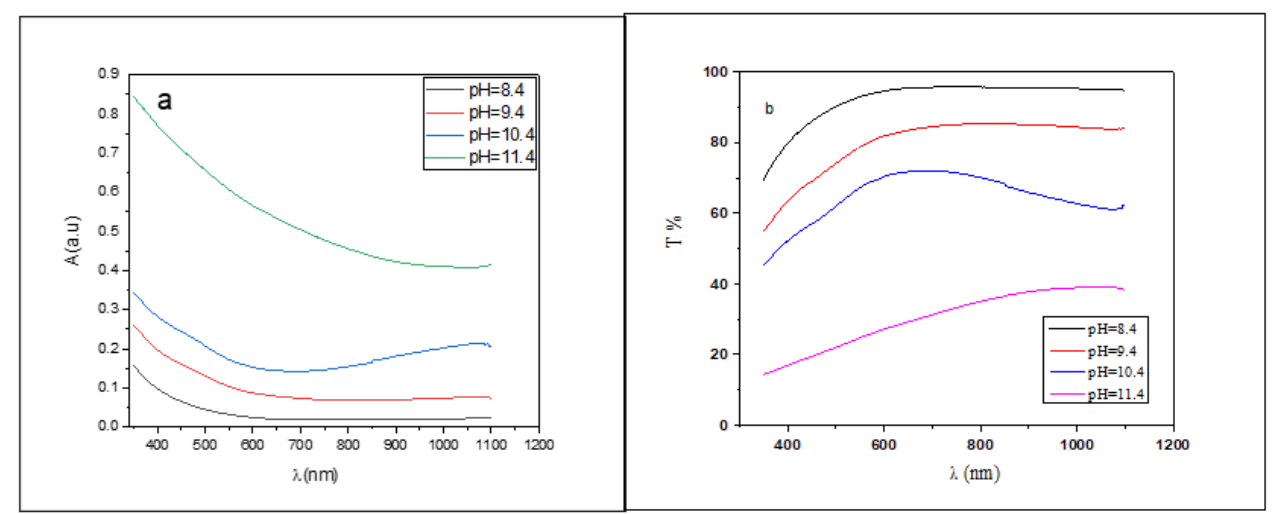

Figure 12. (a) absorption spectrums of $\mathrm{Cu}_{2} \mathrm{~S}$ thin films at various $\mathrm{pH}$ values versus wavelength (b) 1 transmission spectrums of $\mathrm{Cu}_{2} \mathrm{~S}$ thin films at various $\mathrm{pH}$ values versus wavelength with $\mathrm{t}_{\mathrm{d}}=8$ hours, $\mathrm{CuCl}_{2} \cdot 2 \mathrm{H}_{2} \mathrm{O}=0.2 \mathrm{M}$, and $\mathrm{SC}\left(\mathrm{NH}_{2}\right)_{2}=0.1 \mathrm{M}$.

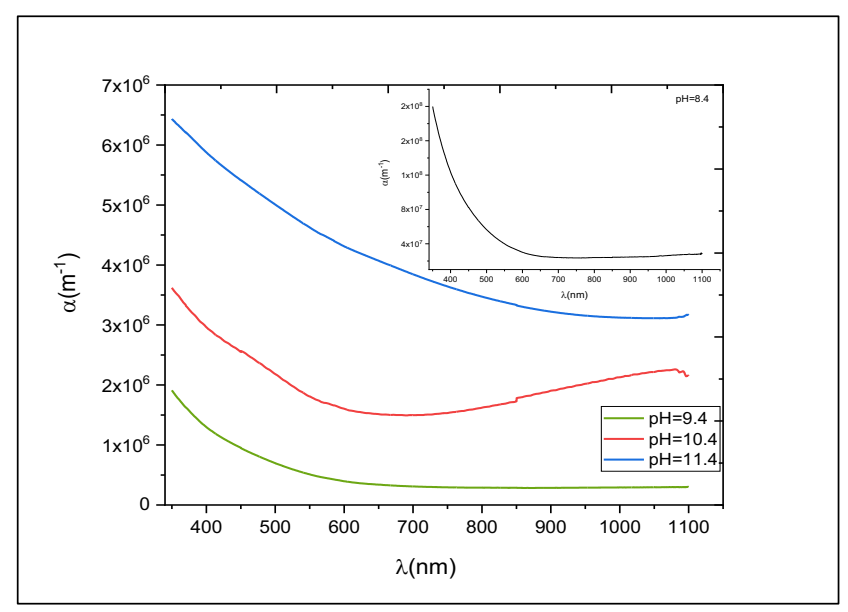

Figure -13 Absorption coefficient of $\mathrm{Cu}_{2} \mathrm{~S}$ thin films versus wavelength at different $\mathrm{pH}$ with $\mathrm{t}_{\mathrm{d}}=8$ hours, $\mathrm{CuCl}_{2} .2 \mathrm{H}_{2} \mathrm{O}=0.2 \mathrm{M}$, and $\left[\mathrm{SC}\left(\mathrm{NH}_{2}\right)_{2}=0.1\right.$ $\mathrm{M}$.

The high absorption coefficient of $\mathrm{Cu}_{2} \mathrm{~S}$ thin films $\left(\sim 1.999 \times 10^{8}-\right.$ $\left.6.435 \times 10^{6} \mathrm{~m}^{-1}\right)$ for $\mathrm{pH}=8.4$ to $\mathrm{pH}=11.4$, indicates again the direct transition band gap of the thin films (Ismail et al., 2019).
According to the acquired measurements of optical transmission, The direct energy band gap of the $\mathrm{Cu}_{2} \mathrm{~S}$ thin films was calculated from the plot of $(\alpha h v)^{2}$ versus (hv) as shown in figure 14 .

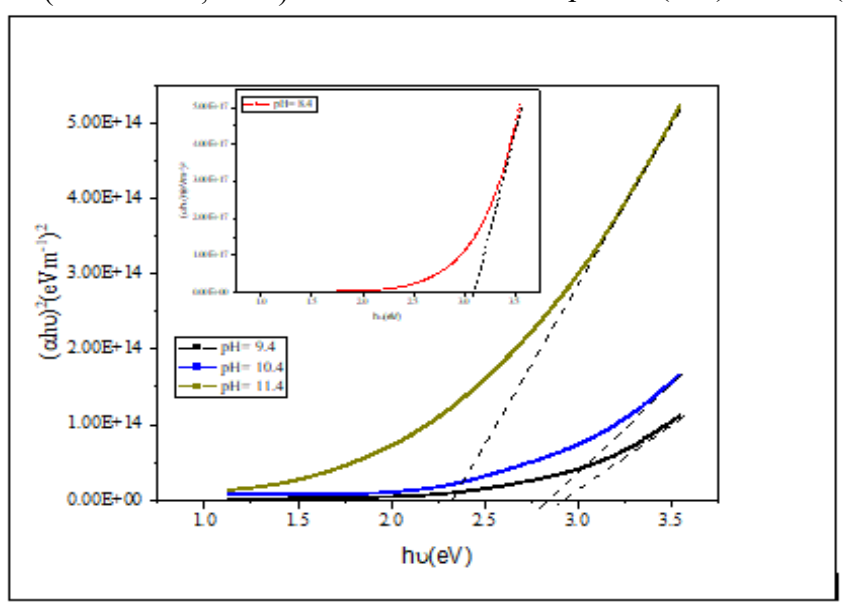

Figure $-14(\alpha h v)^{2}$ with (hv) of various pH values with $\mathrm{t}_{\mathrm{d}}=8$ hours, $\mathrm{CuCl}_{2} \cdot 2 \mathrm{H}_{2} \mathrm{O}=0.2 \mathrm{M}$, and $\mathrm{SC}\left(\mathrm{NH}_{2}\right)_{2}=0.1 \mathrm{M}$.

The result is a sharp optical absorption characteristic, showing homogeneous grain in shape and size and also low defect density

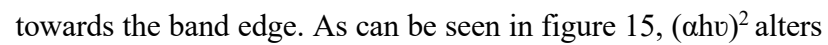
smoothly with (ho) above the bandgap energy (Eg). 
The Eg of $\mathrm{Cu}_{2} \mathrm{~S}$ thin films reduced from (3.02 to $2.32 \mathrm{eV}$ ) as $\mathrm{pH}$ raised from 8.4 to 11.4 as shown in figure 15. The obtaine Eg values slightly larger than obtained by (Muhammed et al., 2019).
This shift in the energy band gap my be attribute due to quantum size effect exhibited by the nanocrystals present in $\mathrm{Cu}_{2} \mathrm{~S}$ film (Hone \& Dejene, 2019; Kotadiya et al., 2012).

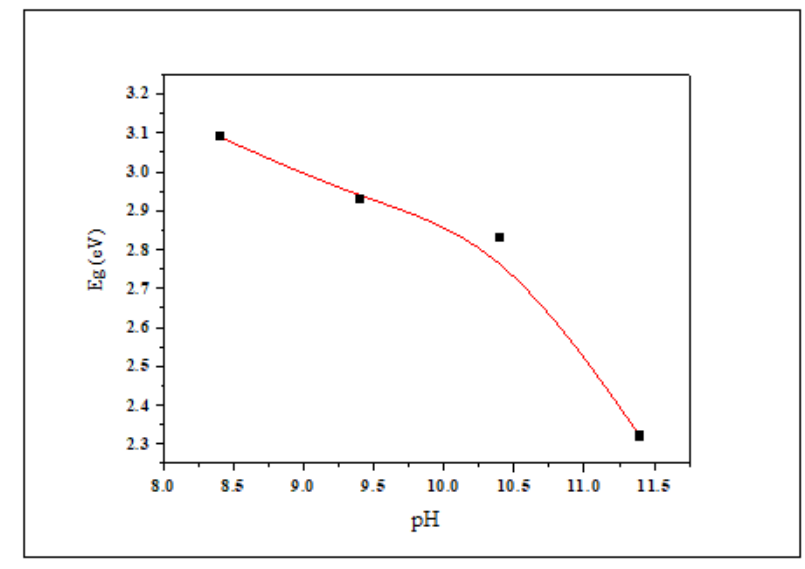

Figure -15 the variation of energy band gap of $\mathrm{Cu}_{2} \mathrm{~S}$ thin film with different $\mathrm{pH}$ at $\mathrm{t}_{\mathrm{d}}=8$ hours, $\mathrm{CuCl}_{2} .2 \mathrm{H}_{2} \mathrm{O}=0.2 \mathrm{M}$, and SC(NH$)_{2}=0.1 \mathrm{M}$.

\section{CONCLUSION}

$\mathrm{Cu}_{2} \mathrm{~S}$ thin films were deposited on glass substrates by the chemical bath deposition technique. The thickness of the deposited $\mathrm{Cu}_{2} \mathrm{~S}$ films increases as the deposition time and $\mathrm{pH}$ increase. The growth rate decreased with deposition time and increased as $\mathrm{pH}$ increased. The XRD results reveal that deposited thin films give an amorphous structure except at a deposition time of 8 hours. $\mathrm{Cu}_{2} \mathrm{~S}$ thin films were obtained at $\mathrm{pH}=10.4$ had the best crystallinity and decreases when the $\mathrm{pH}$ increases to 11.4. It can be seen that from SEM images, the thin films are relatively well synthesized, homogeneous and uniformly covered with some cracks and compact and agglomerations were inceased.The surface of the films is covered with nanowires and a few nanoparticles.

Optical measurement illustrates that the transmission of the $\mathrm{Cu}_{2} \mathrm{~S}$ thin films decreased with increasing $\mathrm{pH}$ and deposition time. The films' transparency increased as wavelength decreased from NIR to UV region. This makes the films be suitable as thin coatings on windows for warm climates. Increasing deposition time and $\mathrm{pH}$ leads to a reduction in the optical energy bandgap.

\section{ACKNOWLEDGEMENTS}

The authors are thankful to the University of Duhok for thier support.

\section{REFERENCES}

Allouche, N. K., Nasr, T. B., Guasch, C., \& Turki, N. K. (2010). Optimization of the synthesis and characterizations of chemical bath deposited $\mathrm{Cu} 2 \mathrm{~S}$ thin films. Comptes Rendus Chimie, 13(11), 1364-1369.

Buba, A., \& Adelabu, J. (2009). Electrical Conductivity of CUXS Thin Film Deposited by Chemical Bath Deposition (CBD) Technique. Nigerian Journal of Basic and Applied Sciences, 17(2), 161-165.

Bulakhe, R. N., Sahoo, S., Nguyen, T. T., Lokhande, C. D., Roh, C., Lee, Y. R., \& Shim, J.-J. (2016). Chemical synthesis of 3D copper sulfide with different morphologies for high performance supercapacitors application. RSC advances, 6(18), 1484414851.
Chopra, K. L. (1969). Thin film phenomena.

CRUZ, J. S., HERNÁNDEZ, S. M., \& CORONEL, J. (2012). Characterization of CuxS thin films obtained by CBD technique at differents annealing temperatures. Chalcogenide Letters, 9(2), 85-91.

Ghdeeb, N. J. (2015). The effect of thickness on the optical properties of $\mathrm{Cu} 2 \mathrm{~S}$ thin films. Iraqi Journal of Physics (IJP), 13(26), 121127.

Guo, K., Chen, X., Han, J., \& Liu, Z. (2014). Synthesis of ZnO/Cu 2 S core/shell nanorods and their enhanced photoelectric performance. Journal of sol-gel science and technology, $72(1), 92-99$.

Ha, E., Xin, Z., Li, D., Zhang, J., Ji, T., Hu, X., Wang, L., \& Hu, J. (2021). Dual-Modified $\mathrm{Cu} 2 \mathrm{~S}$ with $\mathrm{MoS} 2$ and Reduced Graphene Oxides as Efficient Photocatalysts for $\mathrm{H} 2$ Evolution Reaction. Catalysts, 11(11), 1278.

Hodes, G. (2002). Chemical solution deposition of semiconductor films. CRC press.

Hone, F. G., \& Dejene, F. B. (2019). Cationic concentration and pH effect on the structural, morphological and optical band gap of chemically synthesized lead sulfide thin films. Journal of Materials Research and Technology, 8(1), 467-474.

Isac, L., Andronic, L., Enesca, A., \& Duta, A. (2013). Copper sulfide films obtained by spray pyrolysis for dyes photodegradation under visible light irradiation. Journal of Photochemistry and Photobiology A: Chemistry, 252, 53-59.

Isac, L., Duta, A., Kriza, A., Nanu, M., \& Schoonman, J. (2007). Crystal order in $\mathrm{Cu} 2 \mathrm{~S}$ thin films obtained by spray pyrolysis. Journal of optoelectronics and advanced materials, 9(5), 1265-1268.

Ishii, M., Shibata, K., \& Nozaki, H. (1993). Anion distributions and phase transitions in CuS1-xSex $(\mathrm{x}=0-1)$ studied by Raman spectroscopy. Journal of Solid State Chemistry, 105(2), 504511.

Ismail, R. A., Al-Samarai, A.-M. E., \& Muhammed, A. M. (2019). Highperformance nanostructured $\mathrm{p}-\mathrm{Cu} 2 \mathrm{~S} / \mathrm{n}-\mathrm{Si}$ photodetector prepared by chemical bath deposition technique. Journal of Materials Science: Materials in Electronics, 30(12), 1180711818.

Ismail, R. A., Al-Samarai, A. M. E., \& Ali, A. M. M. (2020). Effect of molar concentration of $\mathrm{CuCl} 2$ on the characteristics of $\mathrm{Cu} 2$ S film. Optical and Quantum Electronics, 52(11), 1-14.

Kim, H.-J., Ko, B., Gopi, C. V., Venkata-Haritha, M., \& Lee, Y.-S. (2017). Facile synthesis of morphology dependent $\mathrm{CuS}$ nanoparticle thin film as a highly efficient counter electrode for quantum dot-sensitized solar cells. Journal of Electroanalytical Chemistry, 791, 95-102. 
Kırmızıgül, F., Güneri, E., \& Gümüș, C. (2013). Effects of different deposition conditions on the properties of $\mathrm{Cu} 2 \mathrm{~S}$ thin films. Philosophical Magazine, 93(5), 511-523.

Kotadiya, N. B., Kothari, A. J., Tiwari, D., \& Chaudhuri, T. K. (2012). Photoconducting nanocrystalline lead sulphide thin films obtained by chemical bath deposition. Applied Physics A, 108(4), 819-824.

Lee, J.-H. (2007). Influence of substrates on the structural and optical properties of chemically deposited CdS films. Thin Solid Films, 515(15), 6089-6093.

Li, H., Wang, Y., Jiang, J., Zhang, Y., Peng, Y., \& Zhao, J. (2017). CuS microspheres as high-performance anode material for Na-ion batteries. Electrochimica Acta, 247, 851-859.

Liu, Y., Zhou, Z., Zhang, S., Luo, W., \& Zhang, G. (2018). Controllable synthesis of $\mathrm{CuS}$ hollow microflowers hierarchical structures for asymmetric supercapacitors. Applied Surface Science, 442, 711-719.

Maji, S. K., Dutta, A. K., Bhadu, G. R., Paul, P., Mondal, A., \& Adhikary, B. (2013). A novel amperometric biosensor for hydrogen peroxide and glucose based on cuprous sulfide nanoplates. Journal of Materials Chemistry B, 1(33), 4127-4134.

Makuła, P., Pacia, M., \& Macyk, W. (2018). How to correctly determine the band gap energy of modified semiconductor photocatalysts based on UV-Vis spectra. In: ACS Publications.

Manjulavalli, T., \& Kannan, A. (2015). Effects of deposition time on structural, optical and electrical properties of chemically deposited Cu2S thin films. J. Chem. Tech. Res, 8(11), 607616.

Mohammed, K. A., Ahmed, S. M., \& Mohammed, R. Y. (2020). Investigation of Structure, Optical, and Electrical Properties of CuS Thin Films by CBD Technique. Crystals, 10(8), 684.

Muhammed, A. M., Ibrahim, A. E., \& Ismail, R. A. (2019). Study an Effect of Thiourea Concentration on the Structural, Optical and Electrical Properties of $(\mathrm{Cu} 2 \mathrm{~S})$ film Prepared by Chemical Bath Deposition (CBD). Kirkuk University JournalScientific Studies, 14(3), 97-115.

Nho, P., Ngan, P., Tien, N., \& Viet, H. (2012). Preparation and characterization of low resistivity $\mathrm{CuS}$ films using spray pyrolysis. Chalcogenide Letters, 9(10), 397-402.

Offiah, S., Ugwoke, P., Ekwealor, A., Ezugwu, S., Osuji, R., \& Ezema, F. (2012). Structural and spectral analysis of chemical bath deposited copper sulfide thin films for solar energy conversions. Digest Journal of Nanomaterials and Biostructures, 7(1), 165-173.
OMWOYO, J. G. (2019). CHARACTERIZATION OF Cu2S/SnO2: F PN JUNCTION FOR SOLAR CELL APPLICATIONS KENYATTA UNIVERSITY].

Pathan, H., Desai, J., \& Lokhande, C. (2002). Modified chemical deposition and physico-chemical properties of copper sulphide (Cu2S) thin films. Applied Surface Science, 202(12), 47-56.

Pathan, H., \& Lokhande, C. (2004). Deposition of metal chalcogenide thin films by successive ionic layer adsorption and reaction (SILAR) method. Bulletin of Materials Science, 27(2), 85111.

Podder, J., Kobayashi, R., \& Ichimura, M. (2005). Photochemical deposition of CuxS thin films from aqueous solutions. Thin Solid Films, 472(1-2), 71-75.

Reyes, O., Maldonado, D., Escorcia-García, J., \& Sebastian, P. (2018). Effect of temperature and $\mathrm{pH}$ on direct chemical bath deposition of cuprous oxide thin films. Journal of Materials Science: Materials in Electronics, 29(18), 15535-15545.

Sagade, A. A., \& Sharma, R. (2008). Copper sulphide (CuxS) as an ammonia gas sensor working at room temperature. Sensors and Actuators B: Chemical, 133(1), 135-143.

Schneider, N., Lincot, D., \& Donsanti, F. (2016). Atomic layer deposition of copper sulfide thin films. Thin Solid Films, 600, 103-108.

Shinde, M., Ahirrao, P., Patil, I., \& Patil, R. (2012). Thickness dependent electrical and optical properties of nanocrystalline copper sulphide thin films grown by simple chemical route.

Vas-Umnuay, P., \& Chang, C.-h. (2013). Growth kinetics of copper sulfide thin films by chemical bath deposition. ECS Journal of Solid State Science and Technology, 2(4), P120.

$\mathrm{Xu}, \mathrm{H}$., Dong, J., \& Chen, C. (2014). One-step chemical bath deposition and photocatalytic activity of $\mathrm{Cu} 2 \mathrm{O}$ thin films with orientation and size controlled by a chelating agent. Materials Chemistry and Physics, 143(2), 713-719.

Yu, M., Draskovic, T. I., \& Wu, Y. (2014). Understanding the crystallization mechanism of delafossite $\mathrm{CuGaO} 2$ for controlled hydrothermal synthesis of nanoparticles and nanoplates. Inorganic chemistry, 53(11), 5845-5851.

Zhan, Y., Shao, Z., Jiang, T., Ye, J., Wu, X., Zhang, B., Ding, K., Wu, D., \& Jie, J. (2020). Cation exchange synthesis of twodimensional vertical $\mathrm{Cu} 2 \mathrm{~S} / \mathrm{CdS}$ heterojunctions for photovoltaic device applications. Journal of Materials Chemistry A, 8(2), 789-796. 